\title{
Immunohistochemical study of the phenotypic change of the mesenchymal cells during portal tract maturation in normal and fibrous (ductal plate malformation) fetal liver
}

\author{
Julien Villeneuve ${ }^{1}$, Fanny Pelluard-Nehme ${ }^{2}$, Chantal Combe ${ }^{1}$, \\ Dominique Carles ${ }^{2}$, Christine Chaponnier ${ }^{3}$, Jean Ripoche ${ }^{1}$, \\ Charles Balabaud ${ }^{1}$, Paulette Bioulac-Sage ${ }^{1,2}$ and Sébastien Lepreux*1,2
}

\author{
Address: ${ }^{1}$ INSERM U889, Université Bordeaux2, F-33076 Bordeaux, France, ${ }^{2}$ Service d'Anatomie Pathologique, Hôpital Pellegrin, F-33076 \\ Bordeaux, France and ${ }^{3}$ Département de Pathologie et d'Immunologie, CMU, Genève, Suisse \\ Email: Julien Villeneuve - julienvilleneuve27@hotmail.com; Fanny Pelluard-Nehme - fanny.pelluard-nehme@chu-bordeaux.fr; \\ Chantal Combe - chantal.combe@bordeaux.inserm.fr; Dominique Carles - dominique.carles@chu-bordeaux.fr; \\ Christine Chaponnier - Christine.Chaponnier@medecine.unige.ch; Jean Ripoche - jean.ripoche@gref.u-bordeaux.fr; \\ Charles Balabaud - charles.balabaud@chu-bordeaux.fr; Paulette Bioulac-Sage - paulette.bioulac-sage@chu-bordeaux.fr; \\ Sébastien Lepreux* - sebastien.lepreux@chu-bordeaux.fr \\ * Corresponding author
}

Published: 14 July 2009

Comparative Hepatology 2009, 8:5 doi:10.1186/1476-5926-8-5
Received: I February 2009

Accepted: 14 July 2009

This article is available from: http://www.comparative-hepatology.com/content/8/I/5

(c) 2009 Villeneuve et al; licensee BioMed Central Ltd.

This is an Open Access article distributed under the terms of the Creative Commons Attribution License (http://creativecommons.org/licenses/by/2.0), which permits unrestricted use, distribution, and reproduction in any medium, provided the original work is properly cited.

\begin{abstract}
Background: In adult liver, the mesenchymal cells, portal fibroblasts and vascular smooth muscle cells can transdifferentiate into myofibroblasts, and are involved in portal fibrosis. Differential expression of markers, such as alpha-smooth muscle actin (ASMA), h-caldesmon and cellular retinol-binding protein-I allows their phenotypic discrimination. The aim of our study was to explore the phenotypic evolution of the mesenchymal cells during fetal development in normal liver and in liver with portal fibrosis secondary to ductal plate malformation in a series of Meckel-Gruber syndrome, autosomal recessive polycystic kidney disease and lvemark's syndrome.

Results: At the early steps of the portal tract maturation, portal mesenchymal cells expressed only ASMA. During the maturation process, these cells were found condensed around the biliary and vascular structures. At the end of maturation process, only cells around vessels expressed ASMA and cells of the artery tunica media also expressed $\mathrm{h}$-caldesmon. In contrast, ASMA positive cells persisted around the abnormal biliary ducts in fibrous livers.

Conclusion: As in adult liver, there is a phenotypic heterogeneity of the mesenchymal cells during fetal liver development. During portal tract maturation, myofibroblastic cells disappear in normal development but persist in fibrosis following ductal plate malformation.
\end{abstract}

\section{Introduction}

In the liver, different fibrocompetent cells have been described in accordance with their topography, their morphology and their main functions: portal fibroblasts and vascular smooth muscle cells in the portal tract; hepatic stellate cells (HSC) and "second layer cells" around the centrolobular veins in lobular area (review in Guyot et al [1]). The heterogeneity of these fibrocompetent cells is 
characterised by the expression of different markers. For example, quiescent HSC express cellular retinol-binding protein-1 (CRBP-1) but not alpha-smooth muscle actin (ASMA) or h-caldesmon [2-5]. Vascular smooth muscle cells expressed ASMA and h-caldesmon [6]. Finally, portal fibroblasts expressed neither ASMA nor CRBP-1, but expressed vimentin [3,4]. Myofibroblasts are absent in the normal liver but, during liver fibrosis, these cells can acquire a myofibroblastic phenotype, notably by the expression of ASMA [1,7].

The phenotypic evolution of mesenchymal cells during the fetal human liver development has not been studied with the markers discussed above. The mesenchymal cells derived from the stroma of the septum transversum which is invaded by epithelial cell clusters from hepatic diverticulum during the $4^{\text {th }}$ week of development (WD) [8]. The lobulation of the fetal liver begin near the liver hilum at the $9^{\text {th }} \mathrm{WD}$, and progresses from the hilum to the periphery of the liver until at about 1-month post partum. Concerning the future lobular area, HSC and the second layer cells around the centrolobular veins, derive from mesenchymal cells, as well as the mesenchymal vessels which formed the primitive hepatic sinusoids $[9,10]$. Concerning the portal tract, its centrifugal development is closely associated with intra-hepatic biliary tree development [11]. Depending exclusively on the location of the portal tract along the portal tract tree, between the hilum and the periphery, the sequence of maturation of a portal tract schematically comprises 3 stages [12]: 1) At the ductal plate stage, segments of double-layered cylindrical or tubular structures, called ductal plate, outlined the future portal tract. The future portal tract contains also large portal vein branch and limited stroma; 2) At the ductal plate remodelling stage, the tubular structures become incorporated into the stroma surrounding the portal vein branch and the rest of the ductal plate involutes. Arterial branches are also present; 3) At the remodelled stage, the portal tract is mature: it contains a branch of the portal vein, two branches of the hepatic artery and two bile ducts [13]. In cases of ductal plate malformation, notably observed in Ivemark's renal-hepatic-pancreatic dysplasia or Ivemark's dysplasia syndrome type II (IDS2), in Meckel-Gruber syndrome (MKS) and in autosomal recessive polycystic kidney disease (ARPKD), the portal tract was deeply modified [14-16]. It was characterised by portal tract fibrosis, more mesenchymal cells with ASMA expression and increased number of arteries $[11,17]$.

The aims of our study were to follow principally the ASMA, h-caldesmon, CRBP-1 expression of mesenchymal cells during the normal development of the fetal liver and to explore the phenotypic evolution of the portal tract mesenchymal cells during the abnormal development of fetal liver presenting fibrosis following ductal plate malformation.

\section{Results}

\section{Normal fetal liver - Histology}

In all tissue samples, the fetal liver tissues showed anastomosing sheets of fetal hepatocytes. Each sheet, being two or several cells in thickness, was separated from the others by capillaries. Haematopoiesis was present in all cases and prominent in the capillary lumen or in the Disse space after $12 \mathrm{WD}$. After $11 \mathrm{WD}$, future portal tracts appeared in the parenchyma and developed with a centrifugal manner from the hilum to the periphery of the liver. Depending on the tissue section level (near the hilum or at the periphery), the 3 portal tract maturation stages (described above) were present. In the parenchyma, future centrolobular veins with a thin wall were present.

\section{Normal fetal liver - Immunohistochemistry Alpha-smooth muscle actin (ASMA)}

At the ductal plate stage, all fusiform cells in the stroma between endothelial cells of the future portal vein and the first plate of hepatoblasts expressed ASMA (Figure 1). At the remodelling stage (Figure 2), in addition with fusiform cells under the endothelium of the portal vein and cells in the tunica media of arteries, fusiform cells around the tubular biliary structures enmeshed in the portal stroma and the fusiform cells close to the ductal plate remnants expressed ASMA. The fusiform cells at distance of these two areas were negative for ASMA expression. At the remodelled stage, ASMA expression was restricted to

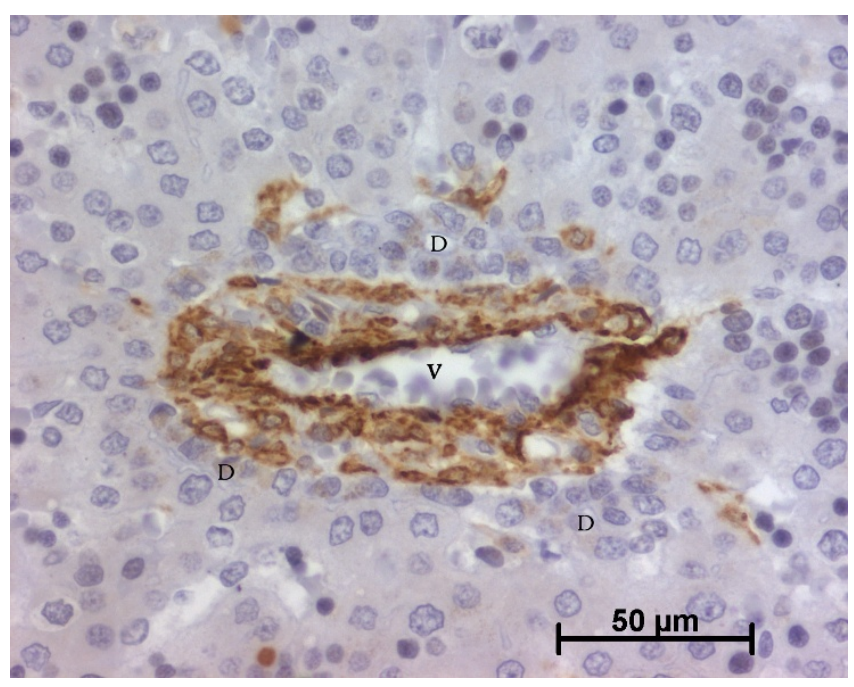

Figure I

Alpha-smooth muscle actin (ASMA) expression in normal fetal liver. At the ductal plate stage, all fusiform cells in the portal stroma express ASMA (I5 WD) (V: portal vein; D: ductal plate). 


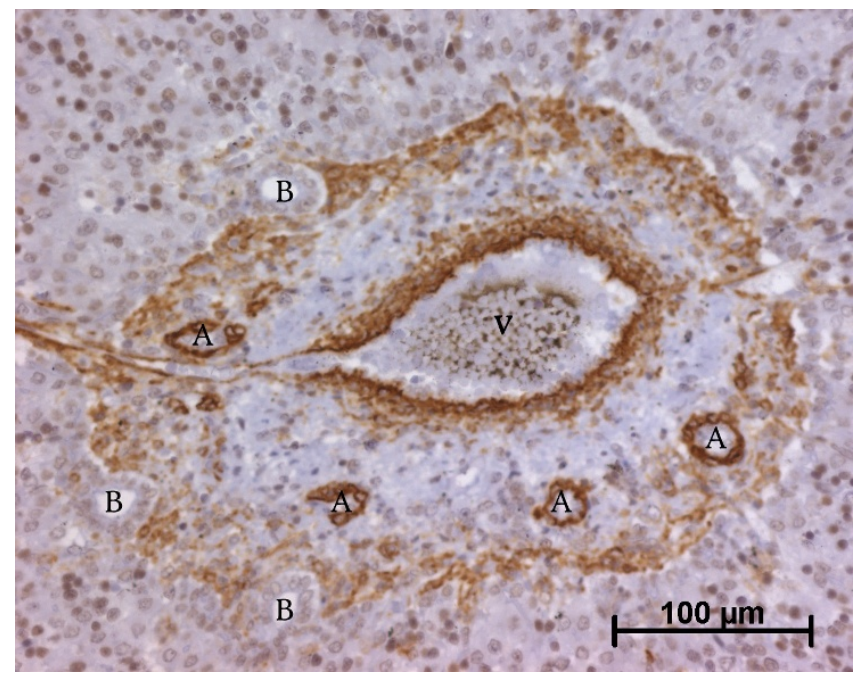

Figure 2

Alpha-smooth muscle actin (ASMA) expression in normal fetal liver. At the remodelling stage, fusiform cells at distance of the vessels and the biliary structures are ASMA negative (I3 WD) (V: portal vein; A: artery; B: bile duct).

the cells in the tunica media of the portal vessels (Figure 3). After 20 WD, a few fusiform cells scattered around large bile ducts in the large portal tracts near the hilum also expressed ASMA. Concerning the lobular area, rare stained HSC were scattered in the parenchyma (Figure 4); only 3 cases $(3 / 28$ cases $)$, respectively at the $13^{\text {th }}, 16^{\text {th }}$ and $21^{\text {th }}$ WD, showed foci of stained HSC. Cells around terminal venules near the portal tract and fusiform cells around

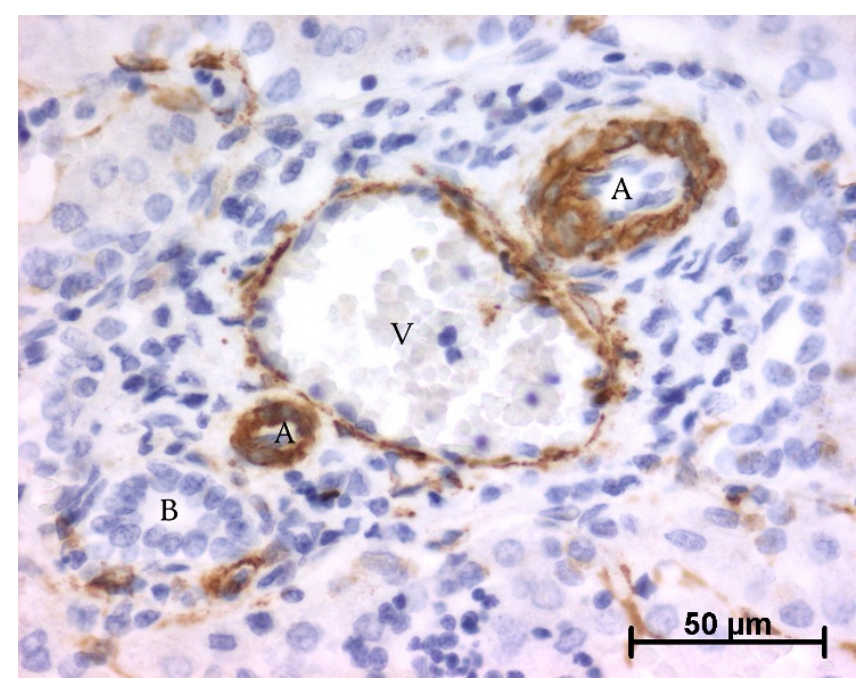

Figure 3

Alpha-smooth muscle actin (ASMA) expression in normal fetal liver. At the remodelled stage, ASMA expression in portal tract is confined to the tunica media of vessels (20 WD) (V: portal vein; A: artery; B: bile duct).

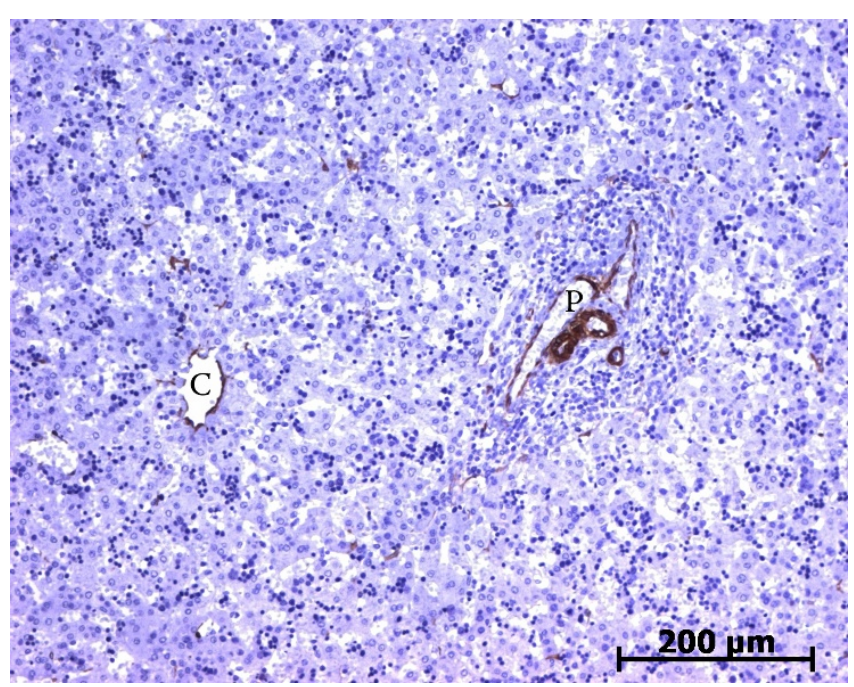

Figure 4

Alpha-smooth muscle actin (ASMA) expression in normal fetal liver. Rare cells are stained with ASMA within the lobule (23 WD) (C: centrolobular vein; P: portal tract).

centrolobular veins expressed ASMA (Figure 5). Hepatocytic cells were not stained.

With double immunofluorescence using anti ASMA and anti vimentin antibodies, negative ASMA fusiform cells within the portal tract notably at the remodelled stage expressed only vimentin (Figures 6 and 7). Endothelial cells of the portal tract vessels, HSC and Kupffer cells were also stained, as previously described in adult liver $[4,18]$.

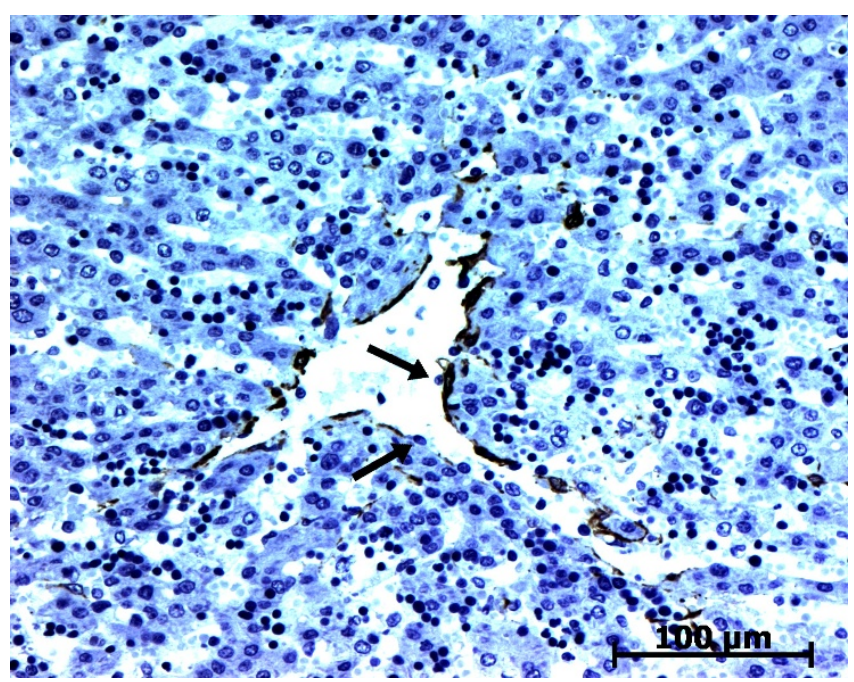

Figure 5

Alpha-smooth muscle actin (ASMA) expression in normal fetal liver. Second layer cells around the centrolobular vein express ASMA, but not endothelial cells (arrows) (23 WD). 


\section{h-Caldesmon}

h-Caldesmon, a specific marker for the smooth muscle cell differentiation last step $[6,19]$, was expressed at 11 WD in the arterial tunica media of the hilum (Figure 8). At the ductal plate stage, after the $11 \mathrm{WD}$, h-caldesmon was not expressed in the future portal tracts. At the remodelling stage, h-caldesmon expression was variably present in fusiform cells of the arterial tunica media (Figures 9 and 10). At the remodelled stage, all the cells in the arterial tunica media were stained. Whatever the stage, the other portal cells, as well as cells in the lobular area, did not express h-caldesmon (Figure 11).

\section{Cellular retinol-binding protein-I (CRBP-I)}

During portal tract development, portal mesenchymal cells never expressed CRBP-1; in contrast biliary cells regularly showed a granular cytoplasmic expression (Figures 12 and 13). This cytoplasmic staining in biliary cells was stronger than in fetal hepatocytes but lower than in the stained cells of the Disse space. In lobular area, until the $13^{\text {th }} \mathrm{WD}$, various number of CRBP-1 stained cells present in the Disse space was observed: no cells in 2 cases, rare cells in 7 cases and numerous cells in 4 cases (Figure 14). After the $13^{\text {th }} \mathrm{WD}$, numerous stained cells were present in all cases, excepted 2 cases where a few cells were observed. Between the $16^{\text {th }} \mathrm{WD}$ and the $18^{\text {th }} \mathrm{WD}$, numerous cytoplasmic processes were visible in these CRBP-1 stained cells present in the Disse space. Except in the oldest case, the density of stained cells was lower than in the adult liver. All cases showed a low cytoplasmic CRBP-1 staining in the hepatocytes and canaliculi were often underlined

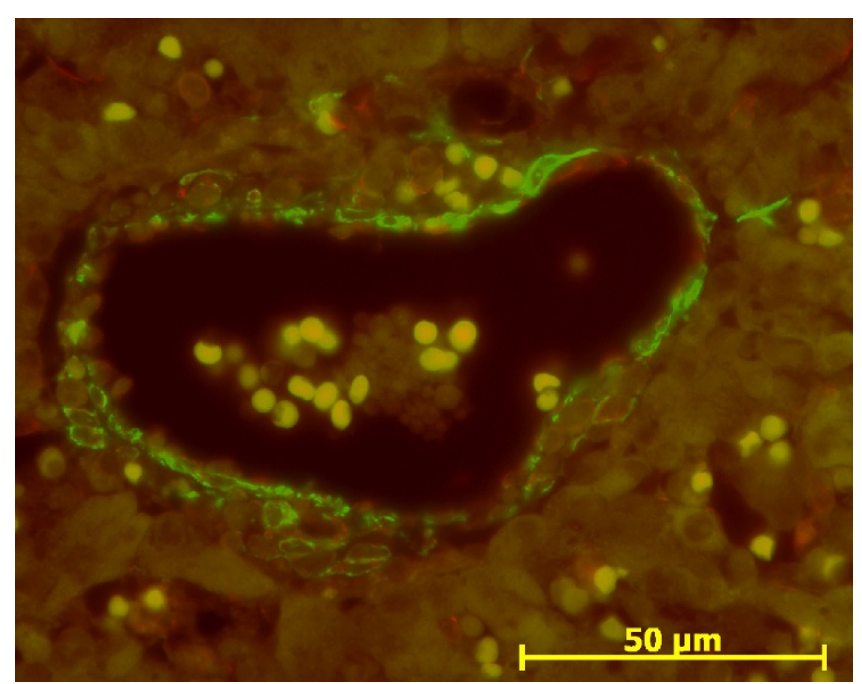

\section{Figure 6}

Double immunofluorescence with ASMA (green)/ vimentin (red) in normal fetal liver. At the ductal plate stage, mesenchymal cells around portal vein express ASMA (green) (I3 WD).

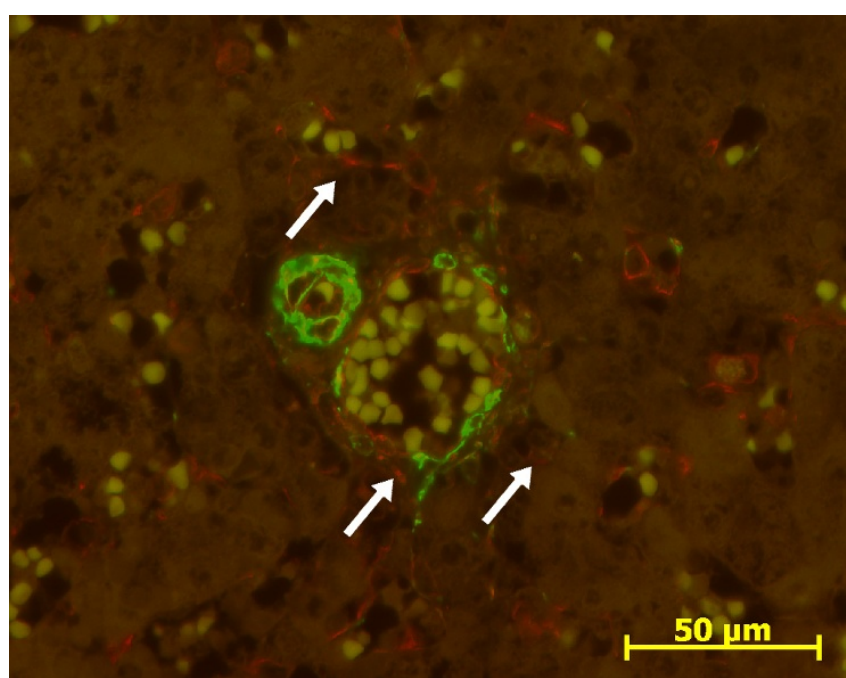

\section{Figure 7}

Double immunofluorescence with ASMA (green)/ vimentin (red) in normal fetal liver. At the remodelled stage, cells around portal vein and artery express ASMA (green), and portal fibroblasts (arrows) express only vimentin (red) (3I WD).

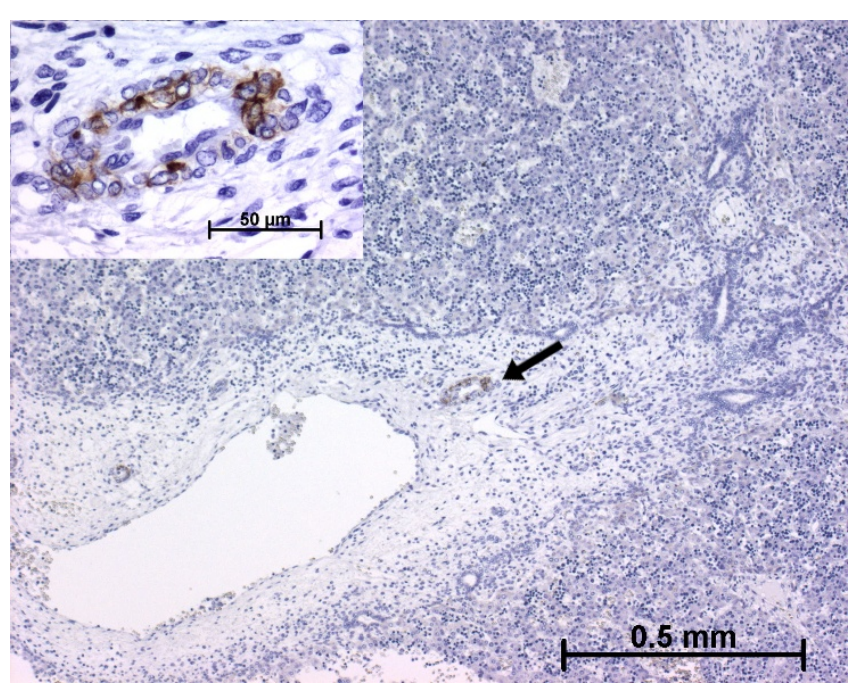

\section{Figure 8}

h-Caldesmon expression in normal fetal liver. At the early time of development, the arterial tunica media cells in the hilum express h-caldesmon (arrow and left insert) (I I WD). 


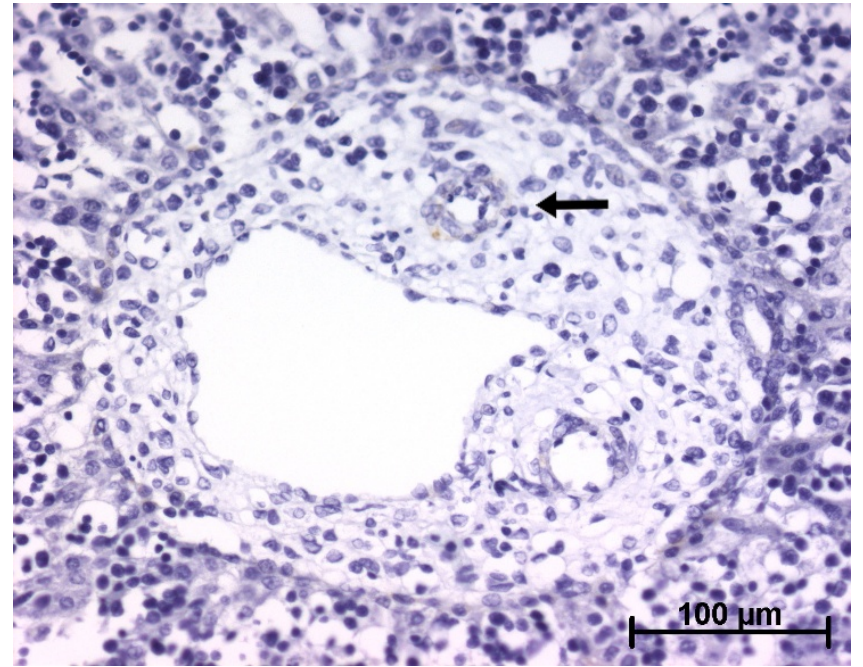

Figure 9

h-Caldesmon expression in normal fetal liver. During the early time of the ductal plate remodelling, $h$-caldesmon is not detected in cells around the portal arterial branch (arrow) (I I WD).

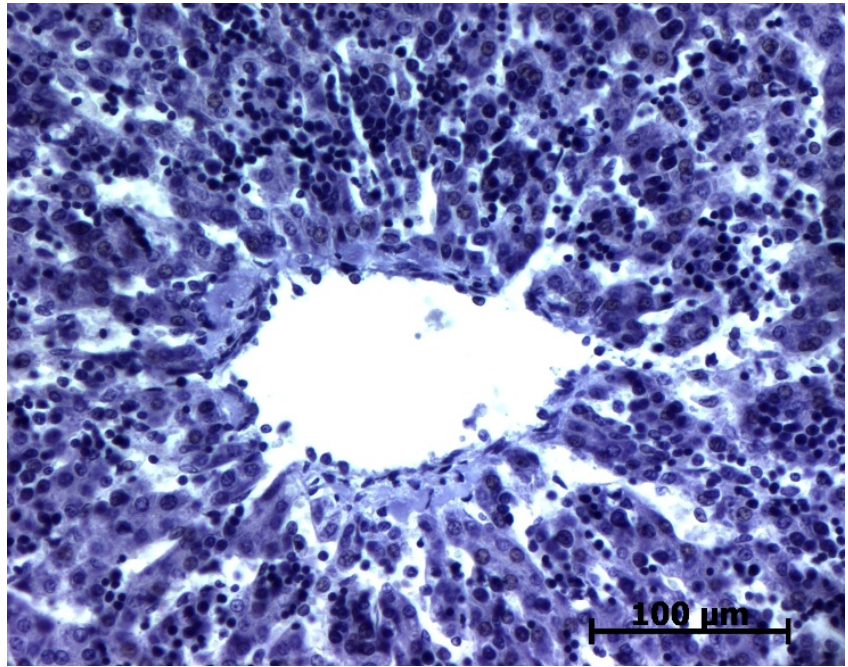

Figure I I

h-Caldesmon expression in normal fetal liver. Around the centrolobular cells, no h-caldesmon expression is found (23 WD).

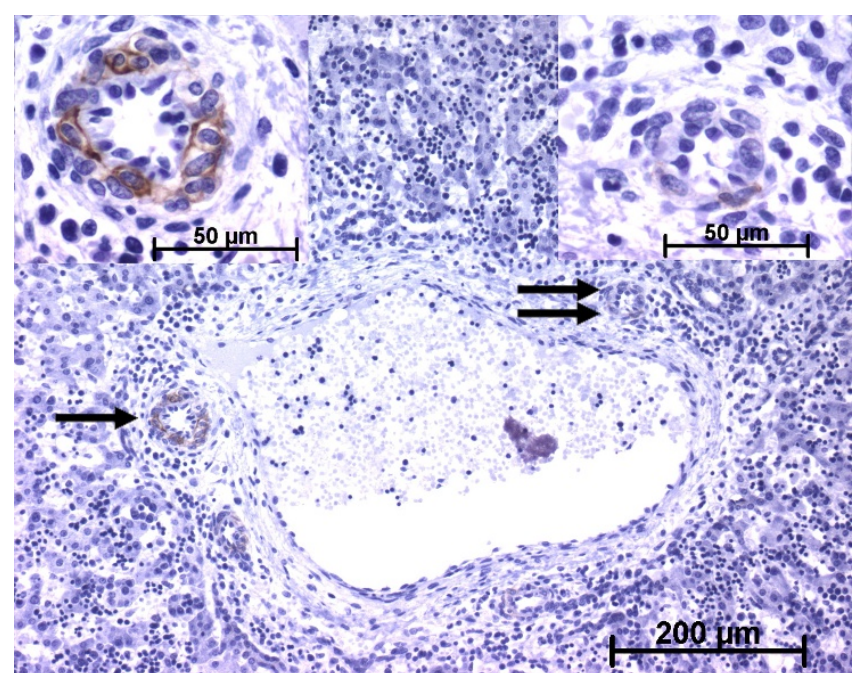

Figure 10

h-Caldesmon expression in normal fetal liver. At advanced time in the remodelling stage, the arterial tunica media cells express faintly $\mathrm{h}$-caldesmon (double arrow, right insert) or more strongly (single arrow, left insert) (I 3 WD). Whatever the stage of portal tract maturation, interstitial stromal cells are not stained.

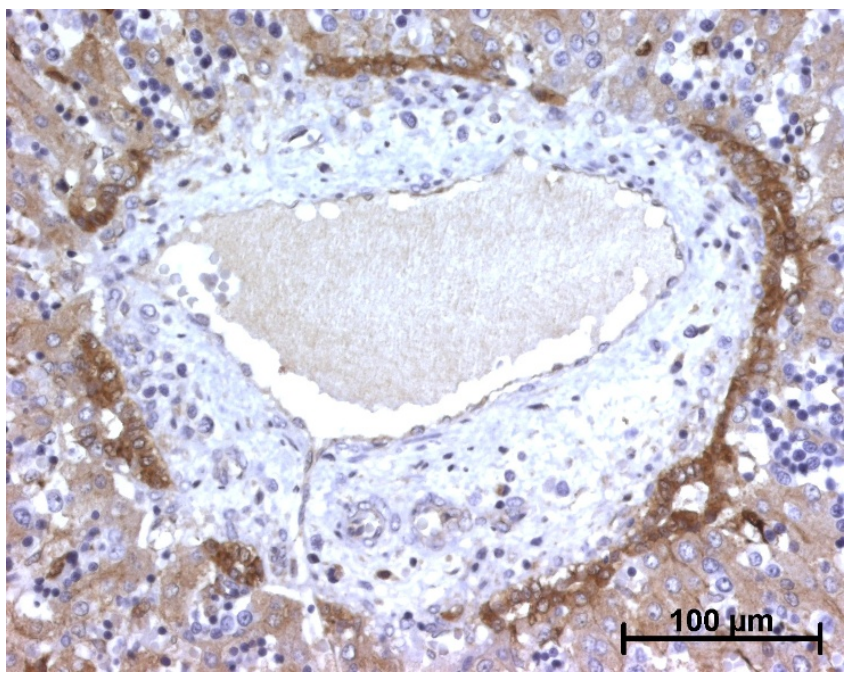

Figure 12

Cellular retinol-binding protein-I (CRBP-I) expression in normal fetal liver. At the beginning of the remodelling stage, biliary structures express CRBP-I stronger than hepatocytes. The portal stromal cells are not stained (I3 WD). 


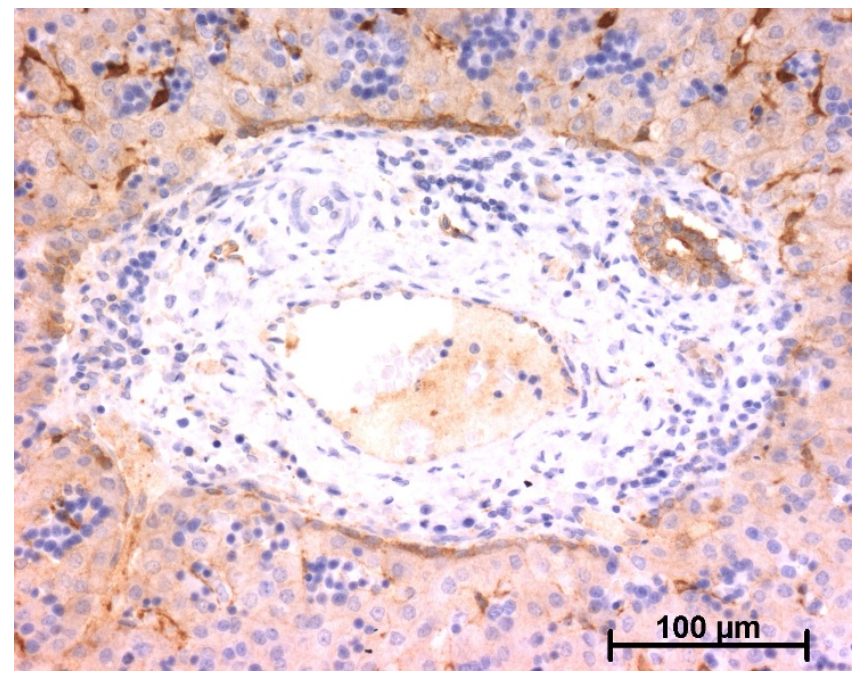

\section{Figure I 3}

Cellular retinol-binding protein-I (CRBP-I) expression in normal fetal liver. At a late stage of the remodelling stage, biliary structures express CRBP-I stronger than hepatocytes. The portal stromal cells are not stained (20 WD).

by a reinforcement of the CRBP-1 staining (Figure 15). Fusiform cells around centrolobular veins expressed CRBP-1 (Figure 16).

\section{CD34}

During the maturation of the portal tract, endothelial cells of portal vessels, notably the terminal venules, and centrolobular vein are stained (Figures 17, 18, 19 and 20). No portal mesenchymal cell, hepatocytic cell and sinusoidal cell were stained.

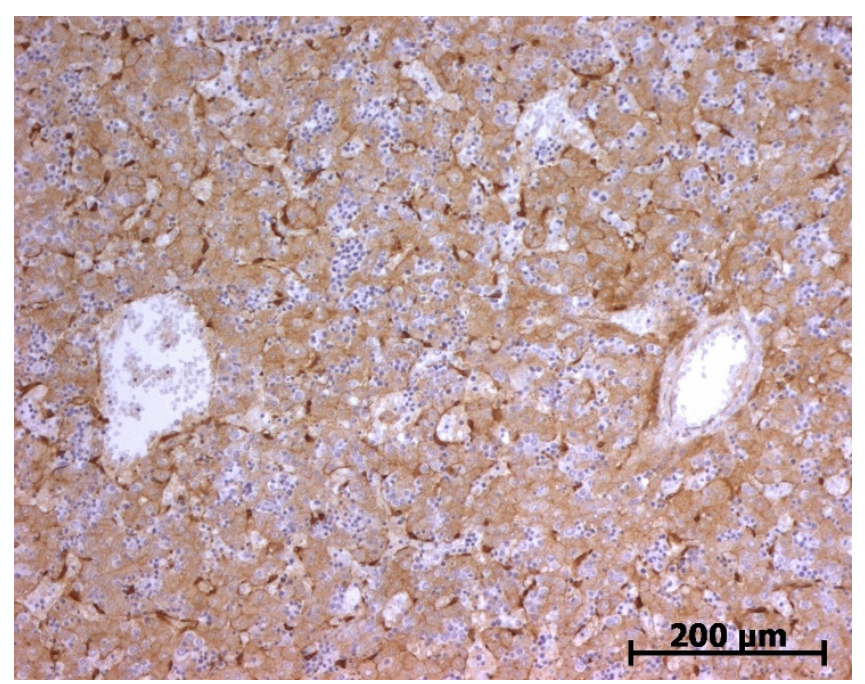

Figure 14

Cellular retinol-binding protein-I (CRBP-I) expression in normal fetal liver. Numerous HSC express CRBP$\mathrm{I}$ in the parenchyma (I I WD).

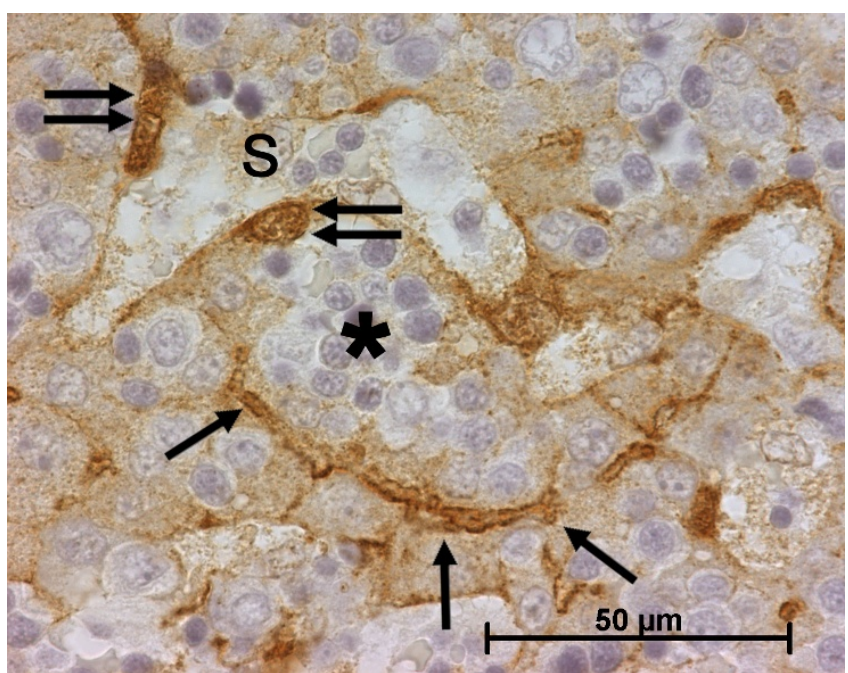

Figure 15

Cellular retinol-binding protein-I (CRBP-I) expression in normal fetal liver. Around the sinusoid (S), CRBPI stained HSC (double arrow) are present in the Disse space $(*)$, where haematopoiesis is observed. Hepatocytes express also CRBP-I with reinforcement in the canaliculi (arrow) (I I WD).

\section{Cytokeratin 19}

The staining of the biliary cells depended of the level of maturation. At the ductal plate stage, the cells of the ductal plate began to express cytokeratin 19 (Figure 21). During the remodelling of the ductal plate (Figure 22) and at the remodelled stage (Figure 23), the biliary ducts were regularly stained. As previously described [20], there was a weak staining of hepatocytes, principally in the youngest

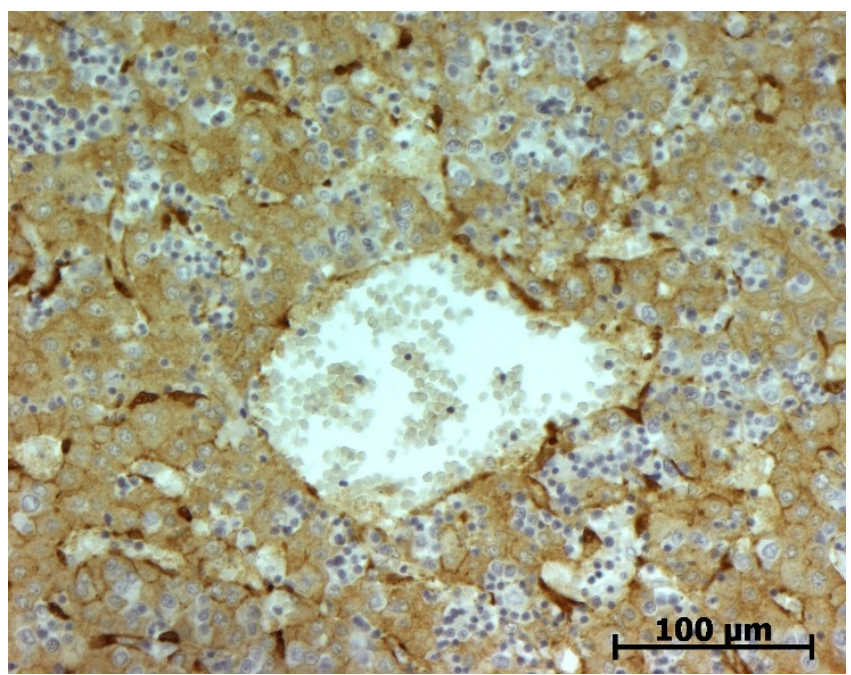

Figure 16

Cellular retinol-binding protein- I (CRBP-I) expression in normal fetal liver. Second layer cells around the centrolobular vein express CRBP-I (II WD). 


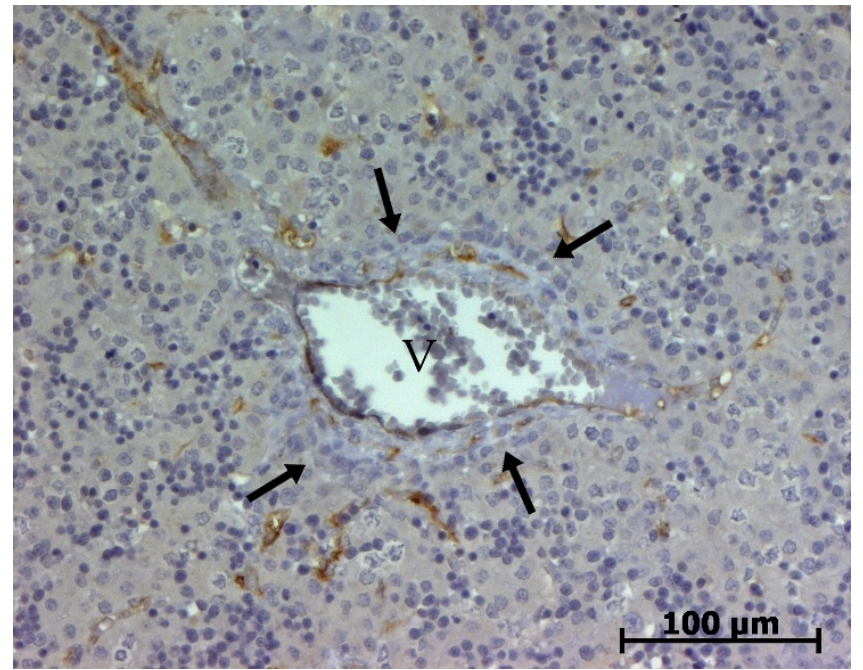

Figure 17

CD34 expression in normal fetal liver. At the ductal plate stage, only endothelial of the portal vein $(\mathrm{V})$ or terminal venules express CD34; portal mesenchymal cells as well as ductal plate (arrows) are negative (I I WD).

cases. In all cases, all fibrocompetent cells were not stained.

\section{Fibrous fetal liver - Histology}

At the beginning of the portal tract development, i.e. ductal plate stage, there were no difference in the portal tract morphology in all pathological livers and normal fetal livers. At the end of the portal tract development, portal tracts were enlarged by fibrosis (Figure 24) with some-

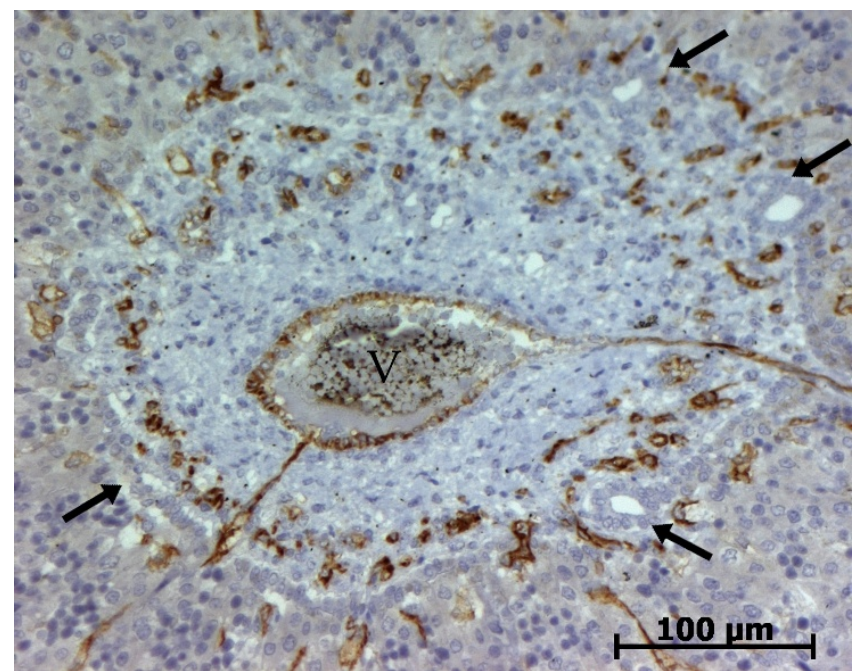

\section{Figure 18}

CD34 expression in normal fetal liver. At the remodelling stage, endothelial of the portal vein $(\mathrm{V})$, arteries or terminal venules express CD34; portal mesenchymal cells as well as biliary structures (arrows) are negative (I I WD).

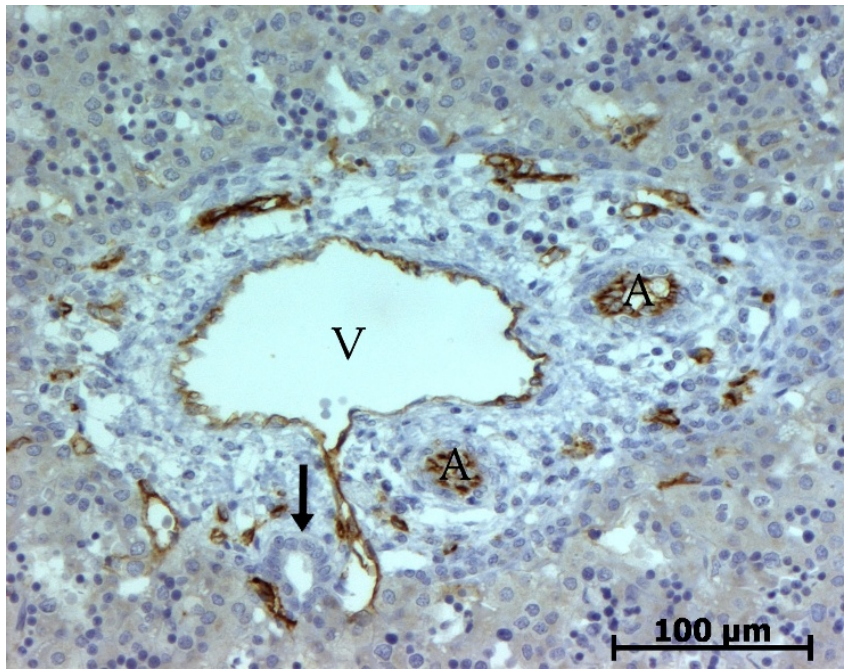

Figure 19

CD34 expression in normal fetal liver. At the remodelled stage, endothelial of the portal vein $(\mathrm{V})$, arteries $(\mathrm{A})$ or terminal venules express CD34; portal mesenchymal cells as well as bile duct (arrow) are negative (I3 WD).

times septa between portal tracts. The circumferential proliferation of bile ducts was low in IDS2, moderate in MKS, and important with dilated bile ducts in ARPKD. In all cases, portal tracts showed a proliferation of fusiform cells around the bile ducts and an increase in the number of hepatic artery branches. The architecture of lobular parenchyma was unchanged.

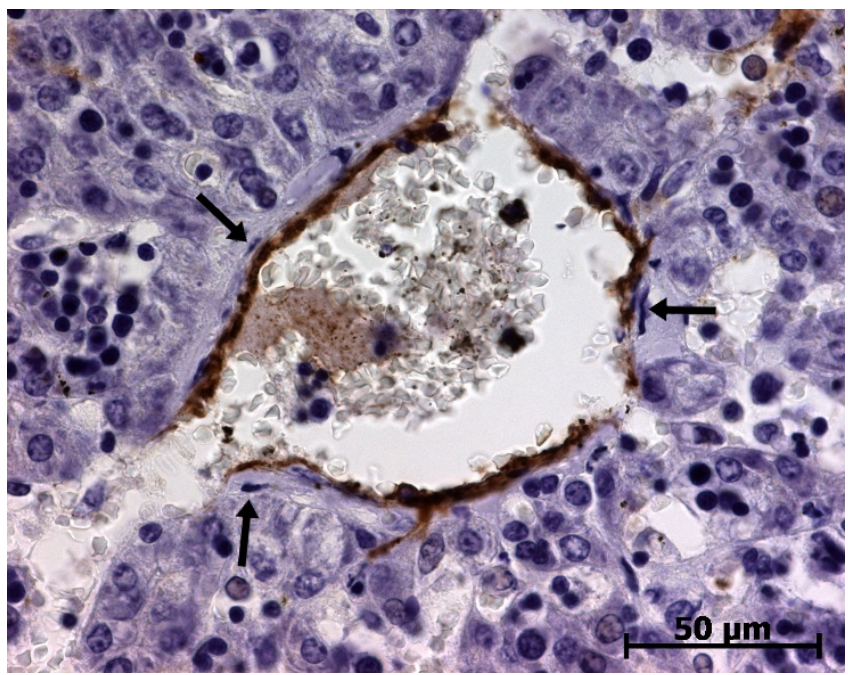

\section{Figure 20}

CD34 expression in normal fetal liver. Around the centrolobular vein, endothelial cells express CD34. The second layer cells are negative (arrows) (23 WD). 


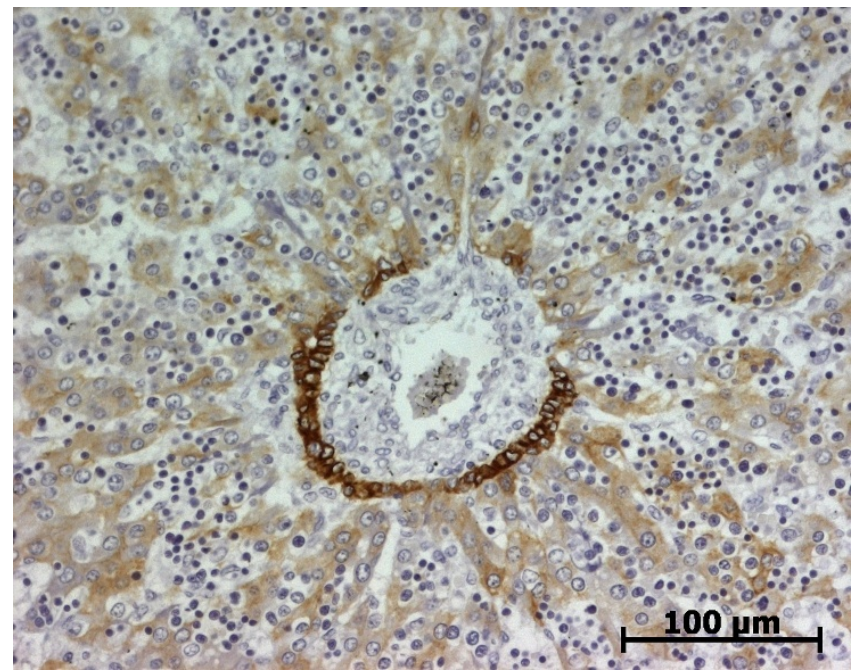

Figure 2 I

Cytokeratin 19 expression in normal fetal liver. At the ductal plate stage, ductal plate express cytokeratine 19 (I I WD).

\section{Fibrous fetal liver - Immunohistochemistry}

Alpha-smooth muscle actin (ASMA)

In the portal tract, the pattern of ASMA expression was the same as in normal fetal liver at the beginning of portal tract development. At the end of development, when portal tracts were enlarged by fibrosis, numerous fusiform cells surrounding the abnormal bile ducts were stained as well as cells in vascular tunica media (Figure 25). In the lobular area, except in one case of MKS, cells in the Disse space did not express ASMA. Fusiform cells around centrolobular vein expressed ASMA.

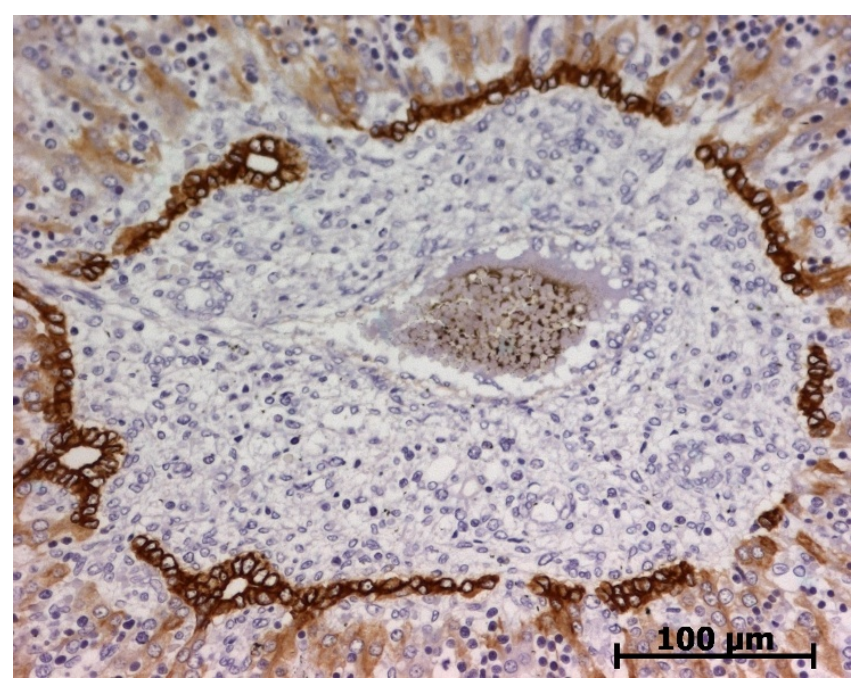

Figure 22

Cytokeratin 19 expression in normal fetal liver. At the remodelling stage, biliary structures express cytokeratine 19 (I I WD).

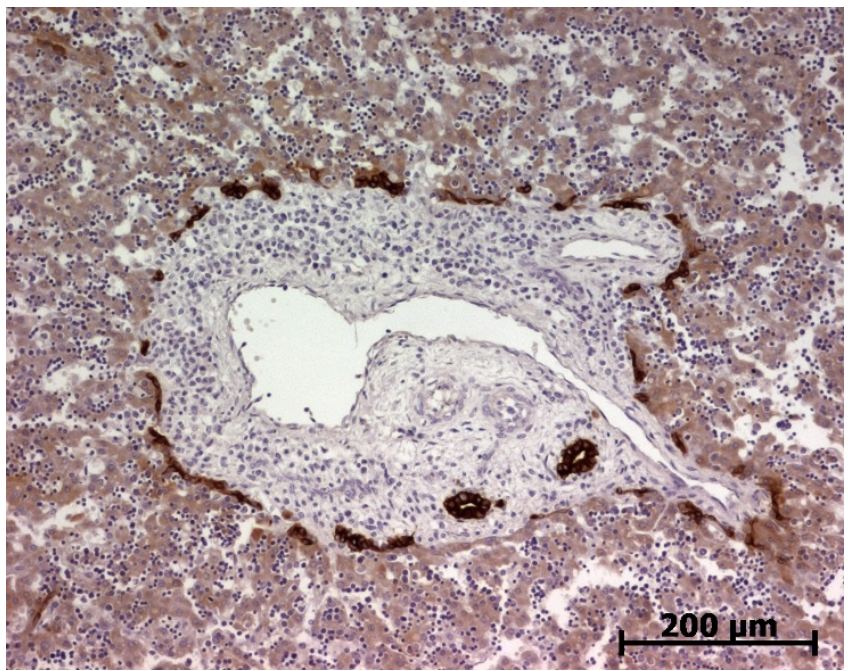

\section{Figure 23}

Cytokeratin 19 expression in normal fetal liver. At the remodelled stage, biliary structures express cytokeratine 19 ( I I WD).

\section{h-Caldesmon}

The evolution of h-caldesmon expression pattern was the same as in the normal fetal liver: in all cases, only cells of the arterial tunica media were stained (Figure 26).

\section{Cellular retinol-binding protein-I (CRBP-I)}

In all cases, portal mesenchymal cells did not express CRBP-1 (Figure 27). In lobular parenchyma, excepted for 3 cases, numerous HSC were stained and exhibited the same pattern of CRBP-1 expression than HSC in the nor-

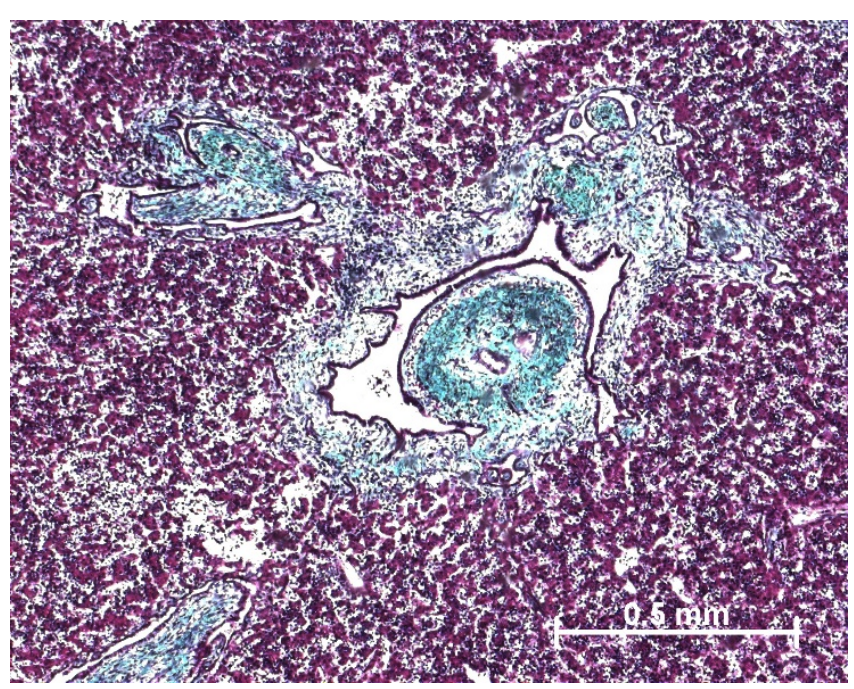

\section{Figure 24}

A case of autosomal recessive polycystic kidney disease. At a late stage of maturation, portal tract is enlarged by fibrosis and contained numerous abnormal bile ducts (trichrome staining)) (22 WD). 


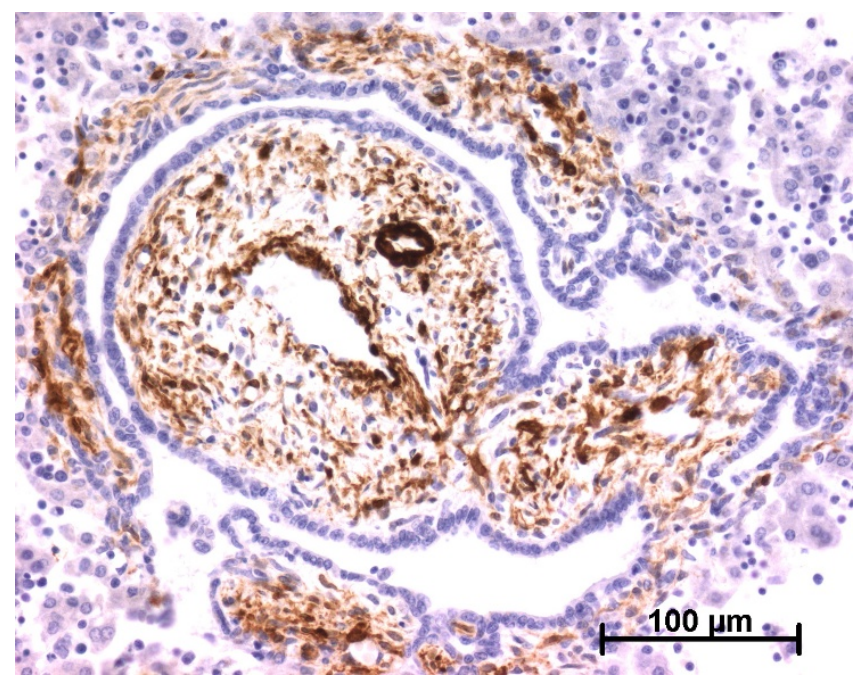

Figure 25

Alpha-smooth muscle actin (ASMA) expression in a case of autosomal recessive polycystic kidney disease. As expected, vessels wall cells express ASMA. Abnormal bile ducts are surrounded by ASMA positive stromal cells ( 22 WD).

mal fetal liver. CRBP-1 expression pattern of hepatocytes and of biliary cells was the same than in the normal fetal liver.

\section{CD34}

As previously described [12], there are more stained capillaries in the enlarged portal tracts than the normal liver.

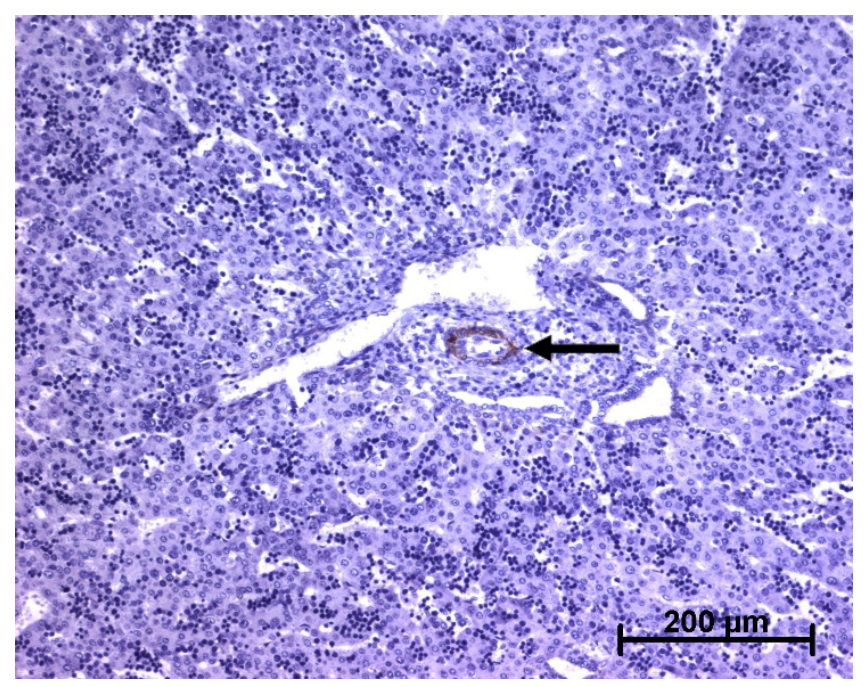

Figure 26

h-Caldesmon expression in a case of autosomal recessive polycystic kidney disease. Only arterial tunica media cells (arrow) express h-caldesmon.; ASMA positive cells around abnormal bile ducts do not expressed $\mathrm{h}$-caldesmon (22 WD).

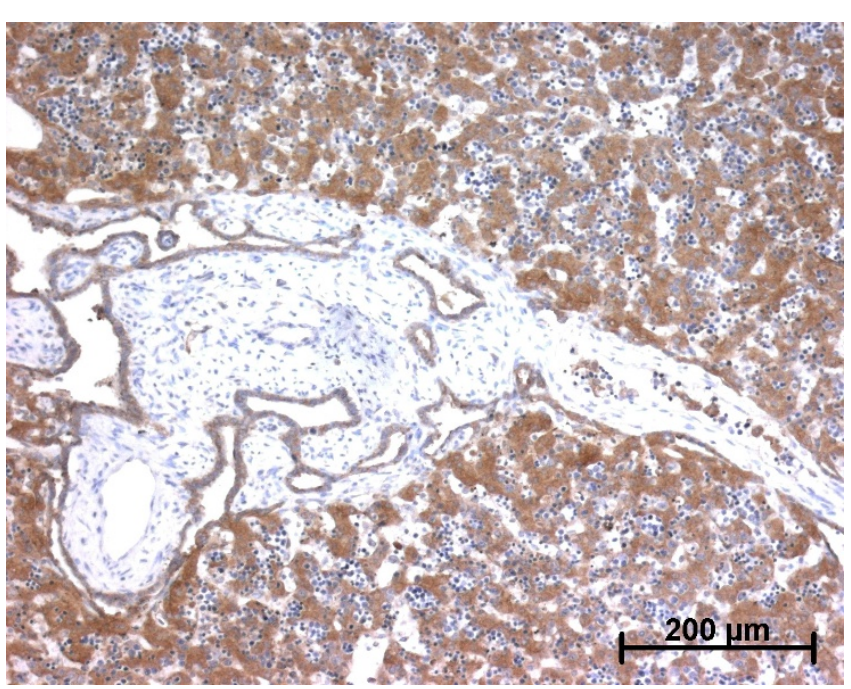

Figure 27

CRBP-I expression in a case of autosomal recessive polycystic kidney disease. Portal stromal cells do not express CRBP-I (22 WD).

These stained capillaries are numerous in the fibrous septa and around the biliary structures (Figure 28). The fusiform mesenchymal cells in the portal tract are not stained (Figure 28).

\section{Cytokeratin 19}

The staining of the biliary cells depended of the level of maturation. In the beginning, the cells of the ductal plates began to express cytokeratin 19. During the abnormal remodeling of the ductal plate, the biliary proliferation was regularly stained (Figure 29). In all cases, cells in the Disse space were not stained.

\section{Discussion}

Our study explored the phenotypic heterogeneity of the mesenchymal cells during liver development, mainly along the portal tract tree in normal and in a large series of fibrous fetal liver. For the first time, 3 markers, which are expressed in hepatic stromal cells were used: ASMA, a cytodifferentiated-related contractile protein expressed notably by smooth muscle cells and myofibroblasts, and 2 others markers poorly used in fetal liver studies, h-caldesmon (150 kDa caldesmon), an isotype of caldesmon expressed by smooth muscle cells, and CRBP-1 which is involved in vitamin A metabolism and is highly expressed in HSC $[3,6,9,19]$.

In the normal fetal liver, phenotypic changes of the portal mesenchymal cells are observed during the 3 stages of the portal tract maturation. At the ductal plate stage, all the mesenchymal cells expressed ASMA and did not expressed CRBP-1 or h-caldesmon. At the remodelling stage, a 


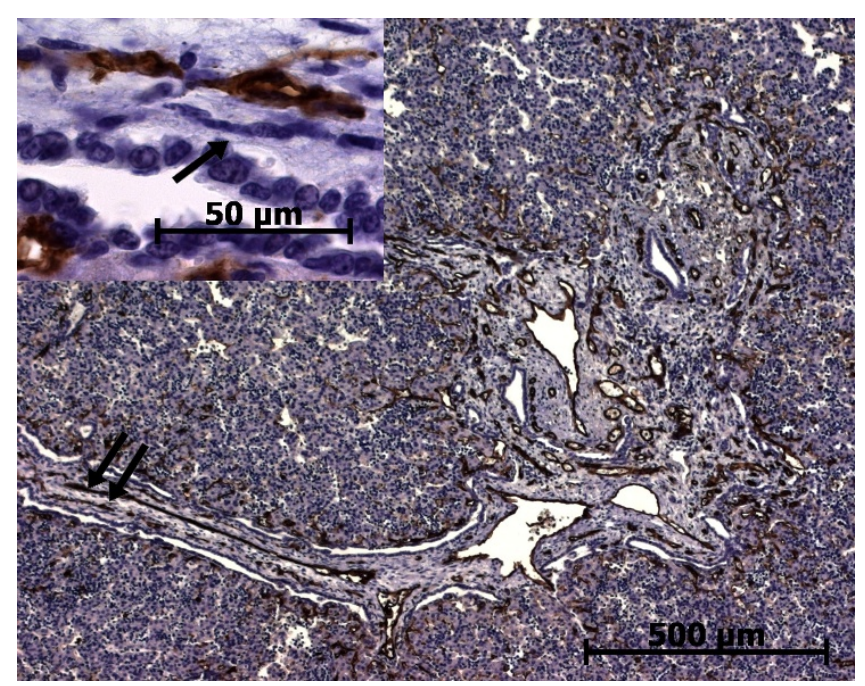

Figure 28

CD34 expression in a case of autosomal recessive polycystic kidney disease. Endothelial cells of the vessels enmeshed in the enlarged portal tract, in the fibrous septa or around the biliary structures express CD34; the portal stromal cells do not expressed CD34 (arrow, left insert) (22 WD).

fibroblastic subpopulation of cells were negative for the 3 markers cited above, but were positive for vimentin, appeared in the middle area of the portal tract at distance from vessels and biliary structures. At the remodelled stage, only cells of arterial tunica media expressed ASMA and h-caldesmon and displayed a smooth muscle pheno-

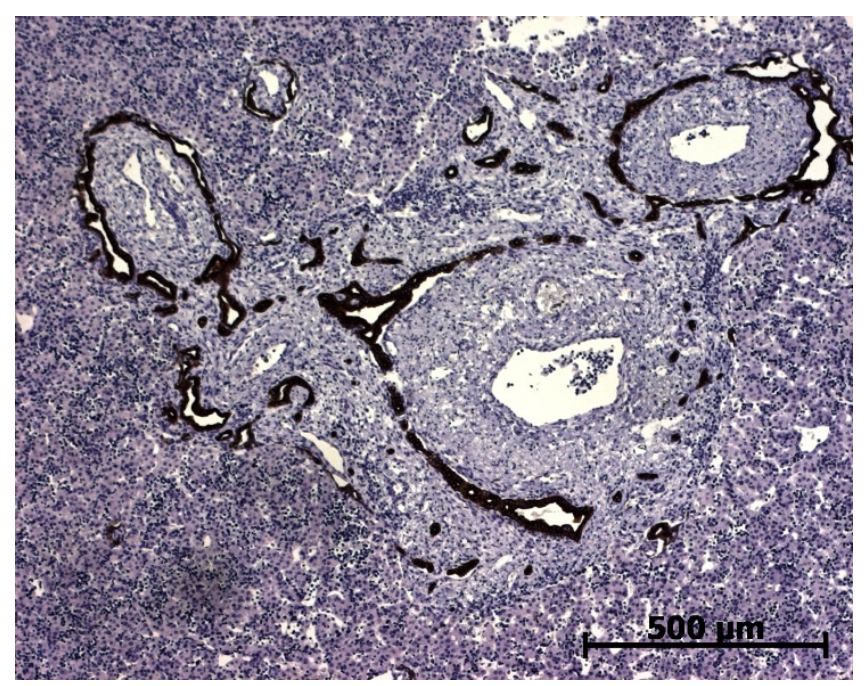

Figure 29

Cytokeratin 19 expression in a case of autosomal recessive polycystic kidney disease. Only biliary structures express cytokeratin 19 (22 WD). type. The cells of portal vein tunica media expressed ASMA, but not h-caldesmon. As reported in adult liver, the connective tissue of the portal tract contained fibroblastic cells, also called portal fibroblasts, which expressed vimentin but not ASMA, CRBP-1 or h-caldesmon $[3,4]$. During the maturation of the portal tract in normal fetal liver, ASMA expressing mesenchymal cells around future portal vein, called myofibroblasts by Libbrecht et al. [12], were replaced or could result from the differentiation into portal fibroblasts and contractile cells of the portal vein tunica media. The sequential involvement of myofibroblastic cells during fetal development was also observed in other organs, notably in cardiac valve or lung $[21,22]$. Concerning the portal vein, we hypothesize that contractile cells in the tunica media could achieve their differentiation after the birth into smooth muscle cells because, in adult normal liver, some cells present in the thin tunica media of portal vein expressed h-caldesmon (data not shown), a more specific and late marker of smooth muscle cell differentiation [6]. We can speculate that this maturation of portal vein smooth muscle cells is related to the change of the portal venous circulation in the liver at birth. Unlike portal vein, the tunica media cells of the hepatic artery branches which were appeared during the remodelling stage, were early completely differentiated into smooth muscle cells, expressing regularly ASMA as well as h-caldesmon. These smooth muscle cells of the tunica media might take origin from the tunica media cells of the upstream arteries. However, we cannot exclude that they differentiate from the portal myofibroblasts.

IDS2, MKS and ARPKD are autosomal recessively inherited disorders characterised in the liver by abnormal development of the portal tract and notably ductal plate malformation [14-16]. In these diseases, the portal tract stroma is enlarged by fibrosis and contained more stromal cells. As described previously in one case of MKS [17], we showed that, in all our pathological cases, a myofibroblastic subpopulation, which expressed only ASMA persists during all the abnormal maturation of the portal tract and is condensed around the abnormal biliary structures. These myofibroblasts which were present in all portal tracts whatever the calibre of bile ducts and not only in the larger-calibre septal bile ducts, as seen in the normal liver until 2 years of age [12], were probably responsible of the excessive deposition of portal extracellular matrix. This myofibroblastic reaction resembles that seen in human liver diseases affecting bile ducts or in experimental models such as bile duct ligation. However, in these cases, myofibroblasts surrounding the ductular proliferation seemed to derive from the transdifferentiation of portal fibroblasts [23-26].

In the lobular area, the development was the same in all our normal and pathological cases. We showed that HSC 
are present early in the Disse space and express CRBP-1. The CRBP-1 staining showed that the thin cytoplasmic processes are poorly developed in the beginning and become more important later. CRBP-1 expressing HSC play a pivotal role in intrahepatic uptake, storage and release of retinoids [27]. As previously described, our study in fetal liver showed that the number of CRBP-1 expressing HSC was variable but gradually increased with the age of development $[9,28]$. As shown here, CRBP-1 was also expressed all along the biliary tree from canaliculi to extrahepatic bile duct; and this expression was reinforced on the apical/luminale membrane. The bile acid synthesis begins at about 5-9 WD and its secretion at about 12 WD. Bile contains retinoids [29]. We assume that, besides the blood retinol transport, there is a biliary transport of retinoids [3].

Table I: Clinical data of non-pathological livers - Part I.

\begin{tabular}{|c|c|c|c|c|}
\hline & $\begin{array}{l}\text { Estimation of gestional age/ } \\
\text { Date of last menstrual } \\
\text { period }\end{array}$ & Sex & Cause of fetus death & Pathology \\
\hline I & $-/ 9$ WA & - & Medical abortion & Extra-uterine pregnancy \\
\hline 2 & II WD/I3 WA & $M$ & Spontaneous abortion & Infection \\
\hline 3 & II WD/I3 WA & $\mathrm{F}$ & Medical abortion & Trisomy 18 \\
\hline 4 & II WD/I3 WA & $M$ & Medical abortion & Amniotic bridle \\
\hline 5 & II WD/I3 WA & $M$ & Spontaneous abortion & Infection \\
\hline 6 & II WD/I3 WA & $\mathrm{F}$ & Medical abortion & Trisomy 21 \\
\hline 7 & II WD/I3 WA & $M$ & Medical abortion & Cervical hygroma \\
\hline 8 & II WD/I3 WA & $M$ & Medical abortion & Encephalocele \\
\hline 9 & 12 WD/I4 WA & $M$ & Medical abortion & Uro-genital abnormality \\
\hline $10 *$ & 13 WD/I5 WA & $\mathrm{F}$ & Spontaneous abortion & - \\
\hline $1 I^{*}$ & 13 WD/I5 WA & $M$ & Spontaneous abortion & - \\
\hline 12 & 13 WD/I5 WA & $M$ & Spontaneous abortion & Muscular dystrophy \\
\hline 13 & 13 WD/I5 WA & $\mathrm{F}$ & Spontaneous abortion & Trisomy 18 \\
\hline 14 & $16 \mathrm{WD} / 18 \mathrm{WA}$ & $M$ & Spontaneous abortion & - \\
\hline 15 & 16 WD/I8 WA & $\mathrm{F}$ & Medical abortion & Trisomy 2I \\
\hline 16 & 17 WD/19 WA & $M$ & Medical abortion & Trisomy 2I \\
\hline 17 & 18 WD/20 WA & $M$ & Spontaneous abortion & Infection \\
\hline 18 & 18 WD/20 WA & $\mathrm{F}$ & Medical abortion & Visceral abnormalities \\
\hline 19 & $20 \mathrm{WD} / 22 \mathrm{WA}$ & $M$ & Medical abortion & Retroplacental hematoma \\
\hline 20 & 20 WD/22 WA & $\mathrm{F}$ & Medical abortion & Visceral abnormalities \\
\hline 21 & $20 \mathrm{WD} / 22 \mathrm{WA}$ & $M$ & Medical abortion & $\begin{array}{l}\text { Premature membranes } \\
\text { rupture }\end{array}$ \\
\hline 22 & $21 \mathrm{WD} / 23 \mathrm{WA}$ & $M$ & Medical abortion & Visceral abnormalities \\
\hline 23 & $21 \mathrm{WD} / 23 \mathrm{WA}$ & $\mathrm{F}$ & Medical abortion & Visceral abnormalities \\
\hline 24 & 23 WD/25 WA & $\mathrm{F}$ & Spontaneous abortion & Infection \\
\hline 25 & 23 WD/25 WA & $\mathrm{F}$ & Medical abortion & - \\
\hline 26 & $23 \mathrm{WD} / 25 \mathrm{WA}$ & $\mathrm{F}$ & Medical abortion & Nanism \\
\hline 27 & 27 WD/29 WA & $M$ & Spontaneous abortion & $\begin{array}{l}\text { Rupture of the uterine } \\
\text { corpus }\end{array}$ \\
\hline 28 & 31 WD/33 WA & $M$ & Stillborn foetus & Anasarca \\
\hline
\end{tabular}

\footnotetext{
*: Cases 10 and II were twins. WD: weeks of development; WA: weeks of amenorrhea; M: male; F: female.
}

\section{Conclusion}

Our study shows that, during the portal tract development, the portal mesenchymal cells are involved in a morphological phenotypic shift from myofibroblasts to portal fibroblasts and vascular smooth muscle cells; in case of portal fibrosis following ductal plate malformation, portal myofibroblasts persist around the abnormal biliary structures.

\section{Methods \\ Human fetal liver specimens}

Normal (28 cases, table 1) and pathological (11 cases, table 2) human fetal tissues were obtained from spontaneous or therapeutic/medical abortion performed in compliance with the French legislation. The causes of fetal death, sex, abnormalities after the autopsy and age according to the date of last menstrual period were summarized in tables 1 and 2. Developmental stages, indicated in weeks after conception, were estimated from the men- 
Table 2: Clinical data of pathological livers - Part II.

\begin{tabular}{|c|c|c|c|c|}
\hline & $\begin{array}{l}\text { Estimation of gestional age/ } \\
\text { Date of last menstrual } \\
\text { period }\end{array}$ & Sex & Cause of fetus death & Pathology \\
\hline 29 & $15 \mathrm{WD} / \mathrm{I} 7 \mathrm{WA}$ & $\mathrm{F}$ & Medical abortion & IDS2 \\
\hline 30 & $19 \mathrm{WD} / 21 \mathrm{WA}$ & $M$ & Medical abortion & IDS2 \\
\hline 31 & $36 \mathrm{WD} / 38 \mathrm{WA}$ & $\mathrm{F}$ & Neonatal death & IDS2 \\
\hline 32 & $13 \mathrm{WD} / \mathrm{I} 5 \mathrm{WA}$ & $M$ & Medical abortion & MKS \\
\hline 33 & $13 \mathrm{WD} / \mathrm{I} 5 \mathrm{WA}$ & $\mathrm{F}$ & Medical abortion & MKS \\
\hline 34 & $15 \mathrm{WD} / \mathrm{I} 7 \mathrm{WA}$ & $\mathrm{F}$ & Medical abortion & MKS \\
\hline 35 & $16 \mathrm{WD} / 18 \mathrm{WA}$ & $M$ & Medical abortion & MKS \\
\hline 36 & $22 \mathrm{WD} / 24 \mathrm{WA}$ & $M$ & Medical abortion & MKS \\
\hline 37 & $13 \mathrm{WD} / 15 \mathrm{WA}$ & $M$ & Medical abortion & ARPKD \\
\hline 38 & $22 \mathrm{WD} / 24 \mathrm{WA}$ & $M$ & Medical abortion & ARPKD \\
\hline 39 & $22 \mathrm{WD} / 24 \mathrm{WA}$ & $\mathrm{F}$ & Medical abortion & ARPKD \\
\hline
\end{tabular}

WD: weeks of development; WA: weeks of amenorrhea; M: male; F: female. IDS2: Ivemark's dysplasia syndrome type 2 - MKS: Meckel-Gruber syndrome - ARPKD: autosomal recessive polycystic kidney disease

strual history and confirmed on anatomic criteria using a regression equation for predicting fetal age [30]. The procedures were in accordance with the European Guidelines for the use of human tissues.

The tissue samples were routinely formalin fixed and paraffin embedded; five $\mu$ m-thick paraffin sections were performed and stained with haematoxylin-eosin-saffron (HES) for diagnosis purposes. Additional sections were stained with Masson's trichrome or used for immunohistochemistry.

\section{Immunohistochemistry}

The immunohistochemical study was routinely performed using an automated immunostainer (Dako A/S, Glostrup, Denmark) with mouse monoclonal primary antibodies against ASMA (1/100, Dako), CRBP-1 (1/100 [31]), h-caldesmon (1/50, Dako), CD34 (Dako), cytokeratine 7 (Dako), and cytokeratin 19 (Dako). The epitopes were detected with the Envision+ system horseradish peroxidase detection kit and revealed with liquid diaminobenzidine (Dako).

For double immunofluorescence, slides were incubated with mouse antibody against vimentin (1/800, Dako) and rabbit antibody against ASMA (1/50, Abcam, Cambridge, UK). Alexa Fluor 568 goat anti-mouse (1/200, Invitrogen, Carlsbad, CA) and Alexa Fluor 488 goat anti-rabbit (1/ 200, Invitrogen, ) were used for the second step.

Sections were examined with a Zeiss Axioplan 2 microscope (Carl Zeiss Microscopy, Jena, Germany) equiped with epiillumination and specific filters. Images were acquired with an AxioCam camera (Carl Zeiss Vision,
Hallbergmoos, Germany) by means of the AxioVision image processing and analysis system (Carl Zeiss Vision).

\section{Competing interests}

The authors declare that they have no competing interests.

\section{Authors' contributions}

JV participated in the histological experiments. FPN gave a fetopathology's expertise. CC participated in the histological experiments. DC gave a fetopathology's expertise. CC participated in the design of immunohistochemical study. JR gave his expertise on fibrogenesis. CB and PBS gave a hepatopathology's expertise. SL was responsible for the conception, performed the immunohistochemical study and wrote the manuscript. All authors have read and approved the final manuscript.

\section{References}

I. Guyot C, Lepreux S, Combe C, Doudnikoff E, Bioulac-Sage P, Balabaud $C$, Desmoulière A: Hepatic fibrosis and cirrhosis: The (myo)fibroblastic cell subpopulations involved. Int J Biochem Cell Biol 2006, 38: I35-15I.

2. Schmitt-Gräff A, Krüger S, Bochard F, Gabbiani F, Denk H: Modulation of alpha smooth muscle actin and desmin expression in perisinusoidal cells in normal and diseased human liver. $\mathrm{Am} J$ Pathol 1991, 138:1233-1242.

3. Lepreux S, Bioulac-Sage P, Gabbiani G, Sapin V, Housset C, Rosenbaum J, Balabaud C, Desmoulière A: Cellular retinol-binding protein-I expression in normal and fibrotic/cirrhotic human liver: different patterns of expression in hepatic stellate cells and (myo)fibroblast subpopulations. J Hepatol 2004, 40:774-780.

4. Van Rossen E, Borght S Vander, Van Grunsven L, Reynaert H, Bruggeman V, Blomhoff R, Roskams T, Geerts A: Vinculin and cellular retinol-binding protein- $I$ are markers for quiescent and activated hepatic stellate cells in formalin-fixed paraffin embedded human liver. Histochem Cell Biol 2009, I 3 I:3 13-325.

5. Nakayama H, Enzan H, Yamamoto M, Miyazaki E, Yasui W: High molecular weight caldesmon positive stromal cells in the capsule of hepatocellular carcinomas. J Clin Pathol 2004, 57:776-777. 
6. Frid M, Shekhonin B, Koteliansky V, Glukhova M: Phenotypic changes of human smooth muscle cells during development: late expression of heavy caldesmon and calpontin. Dev Biol 1992, I 53:185-193.

7. Nouchi T, Tanaka Y, Tsukada T, Sato C, Marumo F: Appearance of alpha-smooth-muscle-actin-positive cells inhepatic fibrosis. Liver 1991, I I: I00-105.

8. Roskams T, Desmet V: Embryology of extra- and intrahepatic bile ducts, the ductal plate. Anat Rec (Hoboken). 2008, 29I(6):628-635.

9. Geerts A: History, heterogeneity, developmental biology, and functions of quiescent hepatic stellate cells. Semin Liver Dis 200I, 2 I:3 I I-335

10. Cassiman D, Barlow A, Borght S Vander, Libbrecht L, Pachnis V: Hepatic stellate cells do not derive from neural crest. J Hepatol 2006, 44: 1098-I I04.

II. Clotmann F, Libbrecht L, Gresh L, Yaniv M, Roskams T, Rousseau G, Lemaigre F: Hepatic artery malformations associated with a primary defect in intrahepatic bile duct development. $J \mathrm{Hepa}$ tol 2003, 39:686-692.

12. Libbrecht L, Cassiman D, Desmet V, Roskams T: The correlation between portal myofibroblasts and development of intrahepatic bile ducts and arterial branches in human liver. Liver 2002, 22:252-258.

13. Crawford A, Lin X, Crawford J: The normal adult human liver biopsy: a quantitative reference standard. Hepatology 1998, 28:323-331.

14. Salonen R: The Meckel syndrome: clinicopathological findings in 67 patients. Am J Med Genet 1984, I 8:67I-689.

15. Torra R, Alos L, Ramos J, Estivill X: Renal-hepatic-pancreatic dysplasia: an autosomal recessive malformation. I Med Genet 1996, 33:409-4I2.

16. Bendon R: Ivemark's renal-hepatic-pancreatic dysplasia: analytic approach to a perinatal autopsy. Pediatr Dev Pathol 1999, 2:94-100.

17. Kuroda N, Ishiura Y, Kawashima M, Miyazaki E, Hayashi Y, Enzan H: Distribution of myofibroblastic cells in the liver and kidney of Meckel-Gruber syndrome. Pathol Int 2004, 54:57-62.

18. Wu H, Tao L, Cramer H: Vimentin-positive spider-shaped Kupffer cells. A new clue to cytologic diagnosis of primary and metastatic hepatocellular carcinoma by fine needle aspiration biopsy. Am J Clin Pathol 1996, 106:517-521.

19. Ceballos K, Nielsen G, Selig M, O'Connell J: Is anti-h-caldesmon useful for distinguishing smooth muscle and myofibroblastic tumors? Am / Clin Pathol 2000, I I 4:746-753.

20. Desmet V, Van Eyken P, Sciot R: Cytokeratins for probing cell lineage relationships in developing liver. Hepatology 1990 , I2:|249-|25|.

21. Shworak N: Angiogenic modulators in valve development and disease: does valvular disease recapitulate developmental signaling pathways? Curr Opin Cardiol 2004, I 9: | 40- I 46.

22. Leslie K, Mitchel J, Woodcock-Mitchell J, Low R: Alpha smooth muscle actin expression in developing and adult human lung. Differentiation 1990, 44: I43-149.

23. Tang L, Tanaka Y, Marumo F, Sato C: Phenotypic change in portal fibroblasts in biliary fibrosis. Liver 1994, 14:76-82.

24. Tuchweber B, Desmoulière $A$, Bochaton-Piallat $M$, Rubbia-Brant $L$, Gabbiani G: Proliferation and phenotypic modulation of portal fibroblasts in the early stages of cholestatic fibrosis in the rat. Lab Invest 1996, 74:265-278.

25. Desmoulière A, Darby I, Monte Alto Costa A, Raccurt M, Tuchweber B, Sommer P, Gabbiani F: Extracellular matrix deposition, lysyl oxydase expression, and myofibroblastic differentiation during the initial stages of cholestatic fibrosis in the rat. Lab Invest 1997, 76:765-778.

26. Lamireau T, Dubuisson L, Lepreux S, Bioulac-Sage P, Fabre M, Rosenbaum J, Desmoulière A: Abnormal hepatic expression of fibrillin-I in children with cholestasis. Am J Surg Pathol 2002, 26:637-646.

27. Blomhoff R, Wake K: Perisinusoidal stellate cells of the liver: important roles in retinol metabolism and fibrosis. FASEB J |99|, 5:27|-277.

28. Enzan H, Himeno H, Hiroi M, Kiyoku H, Saibara T, Onishi S: Development of hepatic sinusoidal structure with special reference to the Ito cells. Microsc Res Tech 1997, 39:336-349.
29. Leo M, Ahmed S, Aleynik S, Siegel J, Kasmin F, Lieber C: Carotenoids and tocopherols in various hepatobiliary conditions. J Hepatol 1995, 23:550-556.

30. Hadlock F, Deter R, Harrist R, Park S: Estimating fetal age: computer-assisted analysis of multiple fetal growth parameters. Radiology. I984, I 52(2):497-50I.

3I. Van Beneden K, Geers C, Van Grunsven L, Pauwels M, Desmoulière A, Verbeelen D, Geerts A, Branden C Van den: CRBP-I in the renal tubulointerstitial compartment of heathly rats and rats with renal fibrosis. Nephrol Dial Transplant 2008, 23:3464-347I.
Publish with Biomed Central and every scientist can read your work free of charge

"BioMed Central will be the most significant development for disseminating the results of biomedical research in our lifetime. "

Sir Paul Nurse, Cancer Research UK

Your research papers will be:

- available free of charge to the entire biomedical community

- peer reviewed and published immediately upon acceptance

- cited in PubMed and archived on PubMed Central

- yours - you keep the copyright 